\title{
Influence of Argon/oxygen Ratio on Linear and Nonlinear Optical Properties of Copper Doped ZnO Films
}

\author{
Xing WEN ${ }^{1}$, Yue HAN ${ }^{1}$, Cheng-Bao YAO ${ }^{1}$, Ke-Xin ZHANG $^{1}$, Jin $^{L^{2}}{ }^{2}$, Wen-Jun SUN ${ }^{1}$ \\ ${ }^{1}$ Key Laboratory of Photonic and Electric Bandgap Materials, Ministry of Education, School of Physics and Electronic \\ Engineering, Harbin Normal University, Harbin, 150025, China \\ ${ }^{2}$ College of Information Science and Engineering, Northeastern University, Shenyang, 110819, China \\ crossref http://dx.doi.org/10.5755/j01.ms.26.2.21568
}

Received 04 September 2018; accepted 16 November 2018

\begin{abstract}
Copper $(\mathrm{Cu})$-doped $\mathrm{ZnO}(\mathrm{CZO})$ films were grown by simultaneous direct current and radio frequency magnetron sputtering technique under the situation of different gas flow rates of $\mathrm{Ar}_{2} \mathrm{O}_{2}$ (1:1, 2:1 and 1:0). The X-ray diffraction patterns revealed the naturally polycrystalline $\mathrm{ZnO}$ films with the predominant reflection (002) peak, which referred to the hexagonal wurtzite structure toward c-axis. The elemental composition of thin films was analyzed by energy dispersive spectroscopy (EDS). The Cu concentrations in thin films increased with Ar ratio of up to 1:0. The EDS spectra of three kinds of elements indicate that $\mathrm{Cu}$-doping has obvious and sophisticated effect on the chemical state of oxygen, but less effect on those of copper and zinc. Furthermore, the nonlinear absorption of CZO films was investigated by the way of Zscan technique. These films demonstrated good nonlinear absorption behavior for the different gas flow rates of Ar: $\mathrm{O}_{2}$. Keywords: nonlinear optics, $\mathrm{ZnO}$, thin films.
\end{abstract}

\section{INTRODUCTION}

Zinc oxide is one of the most interesting II-VI semiconductors. It is highly transparent, inexpensive, nontoxic, which paves its application way as an active luminescent material, gas sensing and piezoelectric transducers etc [1 -5]. To significantly enhance the physical properties of pure Zinc oxide films, all kinds of transition metals [6-10], such as $\mathrm{Bi}, \mathrm{Ag}, \mathrm{Cu}, \mathrm{Co}$ and $\mathrm{Ni}$, have been used as dopants at desired doping concentrations using several deposition techniques. Copper is a prominent luminescence activator in II - VI compounds, meanwhile, it changes the luminescence behavior of $\mathrm{ZnO}$ through produce a localized impurity levels in the bands structure $[11,12]$. Due to the similar ionic radius and electronic shell structure have many physical and chemical properties, which are equivalent to those of $\mathrm{Zn}$ [13]. Up to now, multiple solutions have been performed to fabricate the $\mathrm{Cu}$-doped $\mathrm{ZnO}(\mathrm{CZO})$ films and explore their excellent applications in optoelectronics by a variety of deposition techniques $[14,15]$, which include pulsed laser deposition, simultaneous radio frequency (RF) and direct current (DC) magnetron sputtering (MS) and so on. Recent papers have reported on microstructure and different properties of CZO materials, such as electrical, piezooptical effects, optical and photosensitivity properties et al. Structural and optical properties of $\mathrm{ZnO}$ films with heavy $\mathrm{Cu}$-doping prepared by MS which were reported by Y. Liu et al. [16]. B. Allabergenov et al. [17] reported microstructural analysis and optical characteristics of CZO films. K. Joshi et al. [18] reported band gap widening and narrowing in CZO films. Taking into account the high deposition rate of simultaneous RF and DC MS technique, through independent doping dopant element to the main body in the crystal lattice, film is compact and uniform, the structure and optical properties of controllability. In this paper, we research the effect of argon/oxygen ratio on the structural of CZO films. The nonlinear (NL) optical characteristics of CZO films are investigated. The two-photon absorption (TPA) coefficients of CZO films at argon/oxygen ratio are determined.

\section{MATERIALS AND EXPERIMENT}

Through RF MS ZnO target (99.99\% purity) and DC MS Cu target (99.99\% purity), with different $\mathrm{Ar:O}_{2}$ (1:1, 2:1 and 1:0) flow rates CZO films were on quartz substrates. The substrates were ultrasonically cleaned by alcohol and deionized water. During the deposition, the base pressure and $\mathrm{RF}$ power in the sputtering chamber were $6.0 \times 10^{-4} \mathrm{~Pa}$ and $100 \mathrm{~W}$, respectively. The film growth was performed in a growth environment with a ratio of $\mathrm{Ar}$ (sputter gas): $\mathrm{O}_{2}$ $($ reaction gas $)=20: 10 \mathrm{sccm}$ at a constant working pressure of $1.0 \mathrm{~Pa}$.

Many characterization techniques were used to investigate the properties of $\mathrm{CZO}$ films. The elemental composition of the $\mathrm{CZO}$ films was identified by energy dispersive spectroscopy (EDS, Quanta 200F) attached to the scanning electron microscope (SEM, Quanta 200F). Structural properties have been examined by X-ray diffraction (XRD, D/max-2600/PC). The transmission and absorption spectra were observed at a particular wavelength the extent of 330 to $800 \mathrm{~nm}$ using UV-vis spectrophotometer. The NL optical characteristics were studied using nanosecond Z-scan technique, a Q-switched, frequency doubled $\mathrm{Nd}$ :YAG (1064 $\mathrm{nm}$ ) laser producing $532 \mathrm{~nm}$ wavelength were used as the excitation source.

\footnotetext{
* Corresponding author. Tel.: +86-0451-88060525; fax: +86-0451-

88060525. E-mail address: yaochengbao5@163.com (C.B. Yao)
} 


\section{RESULTS AND DISCUSSION}

\subsection{Elemental composition}

The $\mathrm{Cu}$ atomic concentration in the prepared films has been verified by EDS analysis. Fig. 1 a manifest the EDS spectrum for gas flow rates of $\mathrm{Ar}: \mathrm{O}_{2}=1: 1$. It is confirmed that the deposited films were relation to characteristic $\mathrm{Zn}$ and $\mathrm{O}$ elements as major intense peaks. Meanwhile, the small peaks of $\mathrm{Cu}$ indicated minor composition of $\mathrm{Cu}^{2+}, \mathrm{Cu}^{+}$ has substituted the $\mathrm{Zn}^{2+}$ sites in the $\mathrm{ZnO}$ host matrix. Fig. $1 \mathrm{~b}$ and Fig. $1 \mathrm{c}$ manifest the EDS spectrum for gas flow rates of Ar: $\mathrm{O}_{2}=2: 1$ and Ar: $\mathrm{O}_{2}=1: 0$, respectively. According to the experimental phenomenon, it is noticed that the reactive gas without oxygen will directly affect the transparency of $\mathrm{ZnO}$ films. For example, the gas flow rates of $\mathrm{Ar}: \mathrm{O}_{2}=1: 0$ resulted in the low transparency films. However, the higher ratio of the oxygen in the reactive gas will not always provide a better transparency.

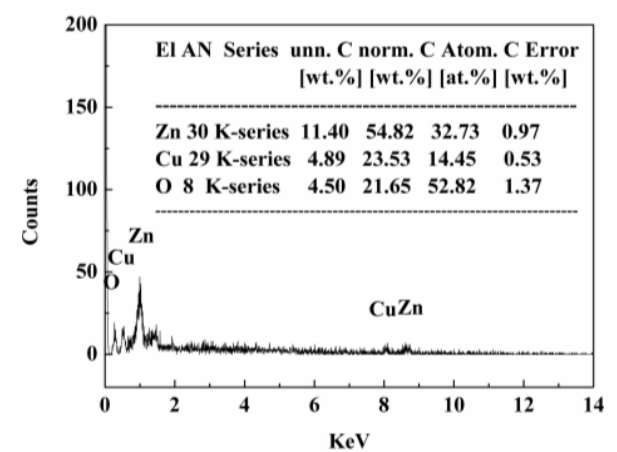

a



$\mathrm{b}$

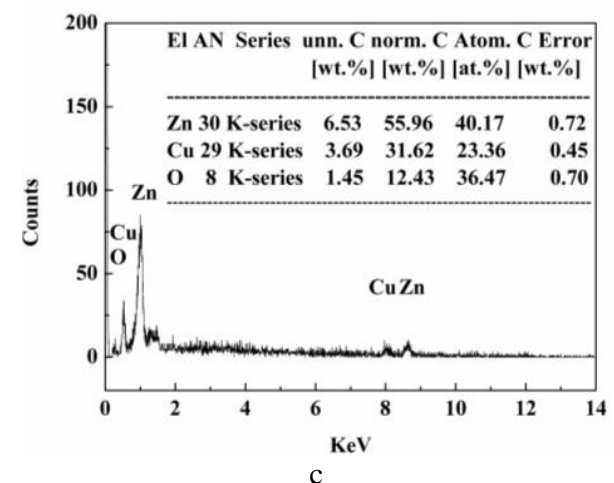

Fig. 1. EDS spectra of CZO films at: $\mathrm{Ar}_{2} \mathrm{O}_{2}=: \mathrm{a}-1: 1 ; \mathrm{b}-2: 1$; $\mathrm{c}-1: 0$

\subsection{Surface features}

In order to further characterize the effects of gas flow rates on the microstructural properties of the film, SEM analysis was confirmed, as shown in Fig. 2. All films show the smooth surface without cracks. From the inset (i) of Fig. 2, it can be observed that is size distribution diagram of CZO films for each sample. The average diameter of lowdimensional structure nanocrystal for all the samples were approximately $36 \mathrm{~nm}$ (for 1:1), $38 \mathrm{~nm}$ (for 2:1), and $40 \mathrm{~nm}$ (for 1:0), respectively, referring to the error value of $\pm 0.14 \mathrm{~nm}$. The particle size is varying from 28 to $48 \mathrm{~nm}$ for different gas flow rates. Maximum grain size of $48 \mathrm{~nm}$ happned at gas flow rates of $\mathrm{Ar}$ : $\mathrm{O}_{2}=1: 0$. In Fig. 2, the particle size linearly increases with the Ar ratio. However, it was smaller than Ar ratio of 1:0 compared to the one with the gas flow rates of $\mathrm{Ar}: \mathrm{O}_{2}=2: 1$. When the Ar ratio increased till to $2: 1$, there is degradation in particle size because of $\mathrm{Cu}$ dopant tends to create more nucleation centers during deposition process. From SEM images, the structure of deposited films can be controlled by adjusting the gas flow rates.
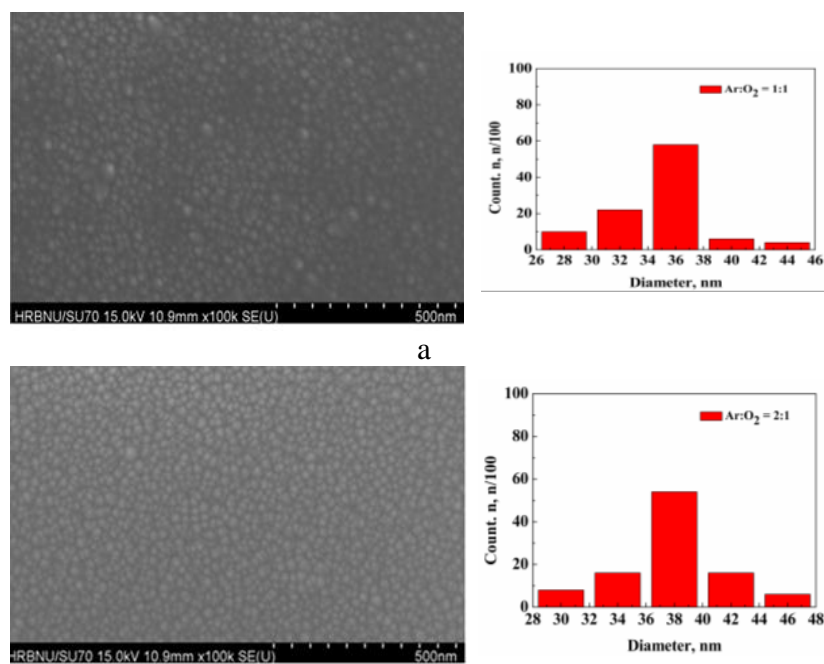

b
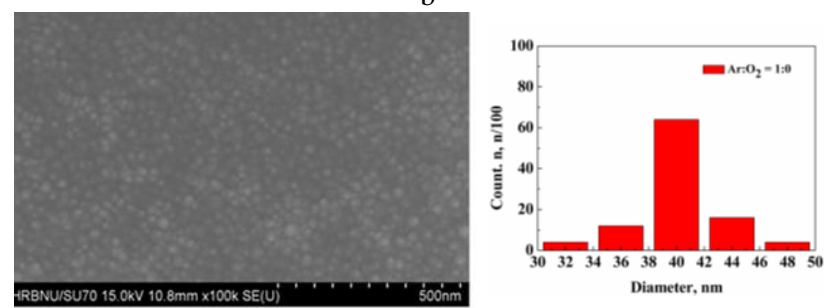

$\mathrm{c}$

Fig. 2. SEM image of the $\mathrm{CZO}$ films at: $\mathrm{Ar}: \mathrm{O}_{2}=: \mathrm{a}-1: 1 ; \mathrm{b}-2: 1$; $c-1: 0$

\subsection{Structural analysis}

Fig. 3 shows the XRD patterns of CZO films prepared with simultaneous RF and DC MS technique. From Fig. 3, the crystal particles are arranged closely and the diffraction intensity of the (002) peak. In addition, CZO films at gas flow rates $\mathrm{Ar}: \mathrm{O}_{2}(2: 1)$ show the peak intensity with the maximum value. With increasing the gas flow rate, as the interplanar spacing ' $d$ ' $(\lambda=2 d \sin \theta)$ increases and the lattice position is replaced by ions of higher ionic radius (ion radius is $\mathrm{Cu}^{+} \sim 0.077 \mathrm{~nm}, \mathrm{Zn}^{2}+0.074 \mathrm{~nm}$ ), the (002) peak position of the zinc oxide structure moves to a lower angle position. The lattice parameters ' $a$ ' and ' $c$ ' values of films can be calculated as [19] 


$$
a=\lambda / \sqrt{3} \sin \theta_{h k l} ;
$$

$$
c=\lambda / \sin \theta_{h k l} .
$$

As shown in Eq. 3, the average crystallite size $\left(D_{h k l}\right)$ of the film was assessed by Debye Scherer equation [20, 21].

$$
D_{h k l}=k \lambda / \beta \cos \theta_{h k l},
$$

where, the X-ray wavelength is represented by $\lambda$, the Bragg diffraction angle is represented by $\theta_{h k l}$, and the full width at half-maximum (FWHM) is represented by $\beta$. The lattice parameters and crystallites size of CZO films will increased under different gas flow rates. Neverthrless, the copper composition does not change the hexagonal structure of $\mathrm{ZnO}$ films. The (002) diffraction peaks, lattice parameters and average crystallite sizes values estimated for the sample show in Table 1.

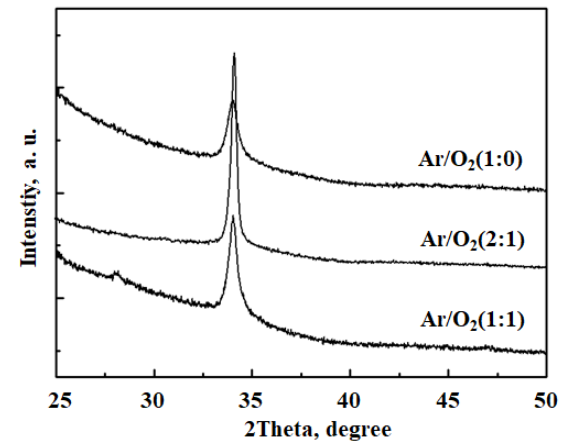

Fig. 3. XRD patterns of CZO films prepared under different gas flow rates

Table 1. The (002) diffraction peaks, lattice parameters and average crystallite size of CZO films under different gas flow rates

\begin{tabular}{|l|c|c|c|c|}
\hline Sample & $2 \theta,^{\circ}$ & $\mathrm{a}, \mathrm{nm}$ & $\mathrm{c}, \mathrm{nm}$ & $D_{h k l}, \mathrm{~nm}$ \\
\hline CZO 1:1 & $34.41^{\circ}$ & 0.3296 & 0.4236 & 36.23 \\
\hline CZO 1:0 & $34.14^{\circ}$ & 0.3292 & 0.4224 & 38.12 \\
\hline CZO 2:1 & $34.20^{\circ}$ & 0.3286 & 0.4198 & 40.34 \\
\hline
\end{tabular}

\subsection{X-ray photoelectron spectroscopy analysis}

XPS spectra of the CZO film at Ar: $\mathrm{O}_{2}=1: 0$ were measured to analyze the valence state of $\mathrm{Cu}$ in $\mathrm{ZnO}$ film. Fig. 4 shows XPS spectra of the $\mathrm{Zn}-2 \mathrm{p}, \mathrm{Cu}-2 \mathrm{p}$, and $\mathrm{O}-1 \mathrm{~s}$ core level regions of the $\mathrm{Cu}-\mathrm{ZnO}$ structures. A doublet at $1021.8 \mathrm{eV}$ and $1044.9 \mathrm{eV}$ is observed in Fig. $4 \mathrm{~b}$ corresponding to the $\mathrm{Zn} 2 \mathrm{p} 3 / 2$ and $2 \mathrm{p} 1 / 2$ core levels. The $\mathrm{Cu}-2 \mathrm{p}$ XPS binding energy region is shown in Fig. $4 \mathrm{c}$. Photoelectron peaks corresponding to the $\mathrm{Cu} 2 \mathrm{p} 3 / 2$ and $2 \mathrm{p} 1 / 2$ core levels were observed at $933.4 \mathrm{eV}$ and $953.7 \mathrm{eV}$. In handbook of XPS [21], 2p3/2 peaks of $\mathrm{Cu}^{0}$ and $\mathrm{Cu}^{+}$in $\mathrm{Cu}_{2} \mathrm{O}$ appear at the same energy, around $932.7 \mathrm{eV}$, and that of $\mathrm{Cu}^{2+}$ in $\mathrm{CuO}$ appears at about $933.6-934 \mathrm{eV}$. In our experiment, we found that the $\mathrm{Cu} 2 \mathrm{p} 3 / 2$ peak of $\mathrm{CZO}$ film at Ar: $\mathrm{O}_{2}=1: 0$ had major $\mathrm{Cu}^{0} / \mathrm{Cu}^{+}(932.7 \mathrm{eV})$ and minor $(933.8 \mathrm{eV})$ components. Therefore, it is concluded that $\mathrm{Cu}$ ions exist in a mixed oxidation state of +1 and +2 and are predominantly in a univalent and bivalent state in CZO film grown in oxygen poor and enriched environment, respectively. The conclusion is also consistent with the analysis of XRD results above.

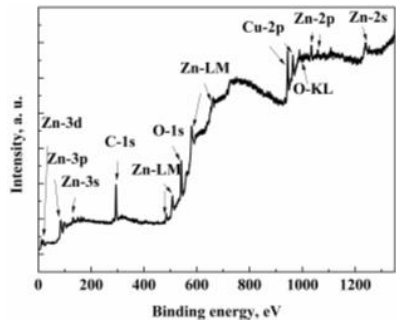

a

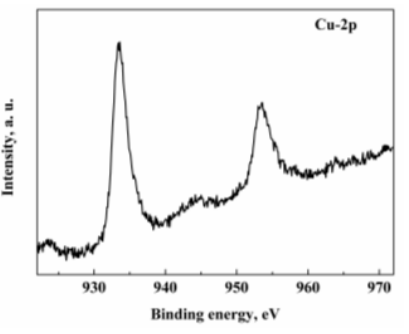

c

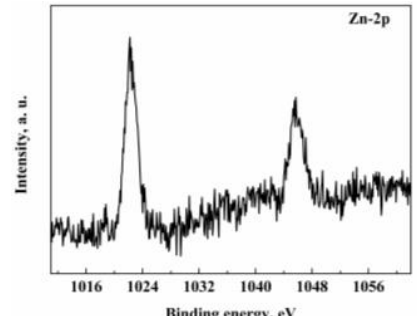

$\mathrm{b}$

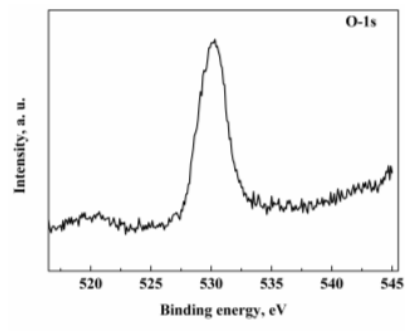

d
Fig. 4. $\mathrm{a}-\mathrm{XPS}$ spectra $(\mathrm{Al} \mathrm{K}=1486.6 \mathrm{eV})$ corresponding to the CZO films; $b-\mathrm{Zn}-2 \mathrm{p} ; \mathrm{c}-\mathrm{Cu}-2 \mathrm{p} ; \mathrm{d}-\mathrm{O}-1 \mathrm{~s}$ core level of CZO films

\subsection{Linear optical properties}

Fig. 5 shows the linear optical absorption and transmission spectrum of the CZO films.
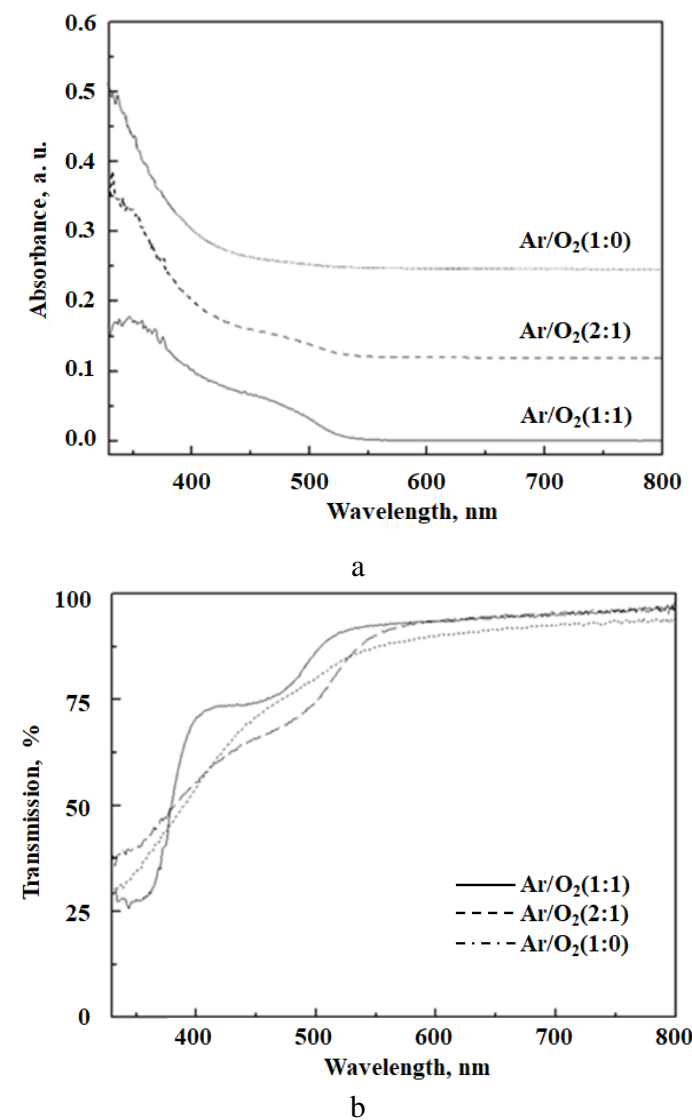

Fig. 5. The absorption (a) and transmission (b) spectra of CZO films formed under different gas flow rates

In Fig. 5 a, the absorption edge conforming to the intrinsic direct band gap in the near UV scope can be 
obviously observed. In the wavelength range of 330-800 nm the transmittances were increased with $\mathrm{Ar}$ ratio till to $2: 1$. Notably, the optical transmittance values turn down the following $85 \%$ while using only Ar reactive gas during thin film deposition. This result reveals the gas flow rates affect the transparency of the films. The optical transmittance decreases due to the surface scattering or interstitial positions of the $\mathrm{ZnO}$ host lattice, as well as the presence of lattice defects in the $\mathrm{ZnO}$ host lattice. In the cause of confirm the direct $E_{\mathrm{P}}$ of $\mathrm{ZnO}$ films, we apply the Tauc relationship mentioned in [22-24]. On the basis of the measured absorption spectra, $(\alpha h v)^{2}$ versus $h v$ data of $\mathrm{ZnO}$ films with adjust gas flow rates are shown in Fig. 6. It apparently indexes that when copper dopants were introduced, the width of the $E_{\mathrm{P}}$ will broaden with the increase of $\mathrm{Ar}: \mathrm{O}_{2}$ ratio. The $E_{\mathrm{P}}$ values of $3.13,3.14$ and $3.27 \mathrm{eV}$ were obtained at the different gas flow rates of Ar: $\mathrm{O}_{2}=1: 1, \quad 1: 0$ and $2: 1$, respectively. We obtained a considerable degression in the $E_{\mathrm{P}}$ energy with gas flow rates. The phenomenon can be ascribed to tough mismatch in the electronegativity of $\mathrm{Cu}$ and $\mathrm{Zn}$ atoms in $\mathrm{ZnO}[25,26]$.



Fig. 6. $(\alpha h v)^{2}$ versus $(h v)$ data of CZO films under different gas flow rates

\subsection{Nonlinear optical properties}

Fig. 7 manifests normalized open-aperture Z-scan data of CZO films with different gas flow rates (Intensity of laser $I_{0}=120 \mathrm{MW} / \mathrm{cm}^{2}$ and wavelength $\lambda_{\mathrm{exc}}=532 \mathrm{~nm}$ ). As shown in Fig. 7, the transmittance curve exhibits the valley characteristic shape. The normalized transmittance for the standard open aperture Z-scan is expressed by the relationship [27]:

$$
T(z, s=1)=\sum\left(\left[-q_{0}\right]^{m} /(m+1)^{3 / 2}\right),
$$

where $\left|q_{0}(0)\right| \triangleleft 1, \quad q_{0}(z)=\alpha_{2} I_{0} L_{\text {eff }} /\left(1+z / z_{0}\right) \quad\left(Z_{0}\right.$ : the Rayleigh rang), and the effective length $L_{e f f}=\mid 1-\exp \left[-(n-1) \alpha_{0} L\right] /\left[(n-1) \alpha_{0}\right] \quad\left(\alpha_{0}: \quad\right.$ the linear absorption coefficient and $L$ : the sample thickness).

The value of $\alpha_{2}$ was calculated by fitting experimental data to Eq. 4. The results prove that the values of the $\alpha_{2}$ were $92.6 \mathrm{~cm}^{2} / \mathrm{GW}(1: 1), 98.9 \mathrm{~cm}^{2} / \mathrm{GW}(2: 1)$ and $98.3 \mathrm{~cm}^{2} / \mathrm{GW}$ (1:0), respectively. So the $E_{\mathrm{P}}(3.26 \mathrm{eV}$ or $380 \mathrm{~nm})$ is bigger than two photon energy $(1.55 \mathrm{eV})$, the absorption process of the $532 \mathrm{~nm}$ is a TPA process. The results show that all samples performed TPA for laser radiation at $532 \mathrm{~nm}$.

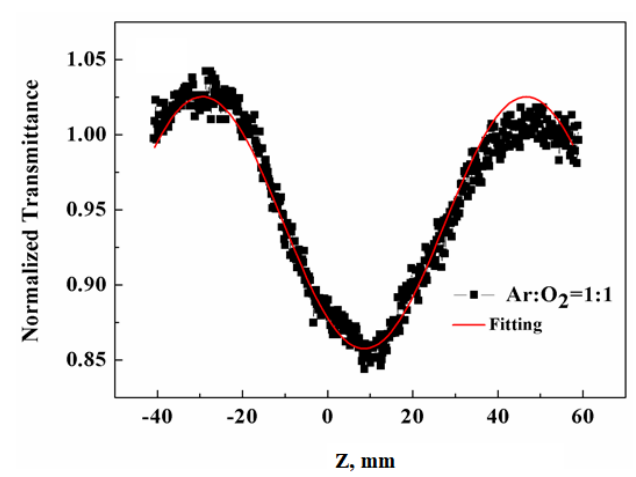

a

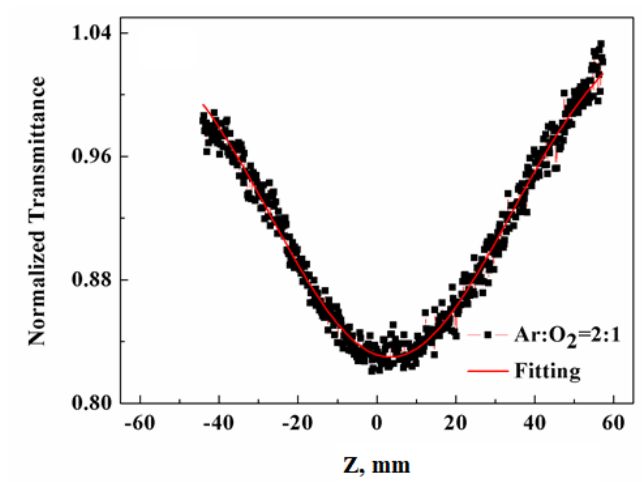

b

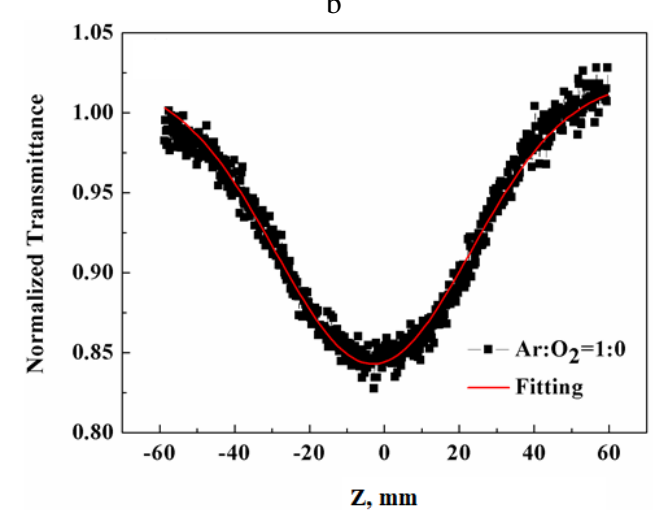

Fig. 7. Normalized open-aperture Z-scan transmittance data of CZO films with different gas rates of $\mathrm{Ar}: \mathrm{O}_{2}$ at $532 \mathrm{~nm}$

\section{CONCLUSIONS}

We synthesized CZO films via magnetron sputtering at various gas flow rates $\mathrm{Ar}: \mathrm{O}_{2}$ (1:1, 2:1 and 1:0) successfully. All CZO films generated in c-axis oriented hexagonal wurtzite crystal structure with $\mathrm{ZnO}$ (002) as a mainly reflection. It was found that as gas flow rates increases, while $\mathrm{ZnO}$ (002) peak strength will be destroyed by $\mathrm{Cu}^{2+}$, $\mathrm{Cu}^{+}$ions instead of $\mathrm{Zn}^{2+}$ ion sites. All samples performed the TPA for laser radiation at $532 \mathrm{~nm}$. The values of the TPA coefficient were $92.6 \mathrm{~cm}^{2} / \mathrm{GW}(1: 1), 98.9 \mathrm{~cm}^{2} / \mathrm{GW}$ (2:1) and $98.3 \mathrm{~cm}^{2} / \mathrm{GW}(1: 0)$, respectively. Our studies reveal that these samples have better nonlinear properties with potential applications in optical devices.

\section{Acknowledgements}

The National Natural Science Foundation of China (No. 11504072). University Nursing Program for Young 
Scholars with Creative Talents in Heilongjiang Province (No. UNPYSCT-2016179).

\section{REFERENCES}

1. Hu, J., Gordon, R.G. Textured Aluminum-Doped Zinc Oxide Thin Films from Atmospheric Pressure ChemicalVapor Deposition Journal of Applied Physics 71 (2) 1992: pp. $880-890$.

https://doi.org/10.1063/1.351309

2. Martinez, O., $\quad$ Plaza, J.L., $\quad$ Mass, J., $\quad$ Capote, B., Dieguez, E., Jimenez, J. Luminescence of Pure and Doped $\mathrm{ZnO}$ Films Synthesised by Thermal Annealing on GaSb Single Crystals Superlattices and Microstructure $42(1-6)$ 2007: pp. $145-151$.

https://doi.org/10.1016/j.spmi.2007.04.024

3. Lupan, O., Pauporte, T., Bahers, T.L., Viana, B., Ciofini, I. Wavelength-Emission Tuning of ZnO NanowireBased Light-Emitting Diodes by $\mathrm{Cu}$ Doping: Experimental and Computational Insights Advanced Functional Materials 21 (18) 2011: pp. 3564-3572. https://doi.org/10.1002/adfm.201100258

4. Hussain, B., Ebong, A., Ferguson, I. Zinc Oxide as an Active N-Layer and Antireflection Coating for Silicon Based Heterojunction Solar Cell Solar Energy Materials and Solar Cells 139 2015: pp. 95-100.

https://doi.org/10.1016/j.solmat.2015.03.017

5. Li, Y., Gong, J., Deng, Y. Hierarchical Structured ZnO Nanorods on ZnO Nanofibers and Their Photoresponse to UV and Visible Lights Sensors and Actuators A: Physical 158 (2) 2010: pp. 176-182.

https://doi.org/10.1016/j.sna.2009.12.030

6. Hassanien, A.S., Akl, A.A., Sáaedi, A.H. Synthesis, Crystallography, Microstructure, Crystal Defects, and Morphology of $\mathrm{Bi}_{\mathrm{x}} \mathrm{Zn}_{1-\mathrm{x}} \mathrm{O}$ Nanoparticles Prepared by Sol-Gel Technique CrystEngComm 20 2018: pp. 1716-1730. https://doi.org/10.1039/C7CE02173A

7. Sahu, D.R. Studies on the Properties of Sputter-Deposited Ag-Doped ZnO Films Microelectronics Journal 38 (12) 2007: pp. $1252-1256$. https://doi.org/10.1016/j.mejo.2007.09.025

8. Tarwal, N.L., Gurav, K.V., Mujawar, S.H., Sadale, S.B., Nam, K.W., Bae, W.R., Moholkar, A.V., Kim, J.H., Patil, P.S., Jang, J.H. Photoluminescence and Photoelectrochemical Properties of the Spray Deposited Copper Doped Zinc Oxide Thin Films Ceramics International 40 (6) 2014: pp. 7669-7677. https://doi.org/10.1016/j.ceramint.2013.12.108

9. Benramache, S., Temam, H.B., Arif, A., Guettaf, A., Belahssen, O. Correlation between the Structural and Optical Properties of Co Doped ZnO Thin Films Prepared at Different $\begin{array}{lll}\text { Film Thickness } & \text { Optik (7) }\end{array}$ 2014: pp.1816-1820. https://doi.org/10.1016/j.ijleo.2013.09.024

10. Siddheswaran, R., Savkova, J., Medlin, R., Ocenaseka, J., Zivotsky, O., Novak, P., Sutta, P. Highly C-Axis Oriented ZnO:Ni Thin Film Nanostructure by RF Magnetron Sputtering: Structural, Morphological and Magnetic Studies Applied Surface Science $316(1)$ 2014: pp. $524-531$.

https://doi.org/10.1016/j.apsusc.2014.08.068

11. Akl, A.A., Mahmoud, S.A., AL-Shomar, S.M., Hassanien, A.S. Improving Microstructural Properties and Minimizing Crystal Imperfections of Nanocrystalline $\mathrm{Cu}_{2} \mathrm{O}$ Thin Films of Different Solution Molarities for Solar Cell
Applications Materials Science in Semiconductor Processing 74 2018: pp. 183-192.

https://doi.org/10.1016/j.mssp.2017.10.007

12. Tao, Y.M., Ma, S.Y., Chen, H.X., Meng, J.X., Hou, L.L., Jia, Y.F., Shang, X.R. Effect of the Oxygen Partial Pressure on the Microstructure and Optical Properties of $\mathrm{ZnO}: \mathrm{Cu}$ Films Vacuum 85 (7) 2011: pp. $744-748$. https://doi.org/10.1016/j.vacuum.2010.11.009

13. Bahsi, Z.B., Oral, A.Y. Effects of $\mathrm{Mn}$ and $\mathrm{Cu}$ Doping on the Microstructures and Optical Properties of Sol-Gel Derived $\mathrm{ZnO}$ Thin Films Optical Materials 29 (6) 2007: pp. $672-678$. https://doi.org/10.1016/j.optmat.2005.11.016

14. Jeon, J.H., Jeong, S.Y., Cho, C.R., Lee, S.A., Lee, W.J., Ahn, H.S., Kim, H.S. Heteroepitaxial Relation and Optical Properties of $\mathrm{Cu}$-Doped $\mathrm{ZnO}$ Films Grown by Using Pulsed Laser Deposition Journal-Korean Physical Society 54 (92) 2009: pp. $858-862$. https://doi.org/10.3938/jkps.54.858

15. Sahu, D.R. Properties of Doped $\mathrm{ZnO}$ Thin Films Grown by Simultaneous DC and RF Magnetron Sputtering Materials Science and Engineering: B 171 (1-3) 2010: pp. 99-103. https://doi.org/10.1016/j.mseb.2010.03.080

16. Liu, Y., Liu, H.N., Yu, Y., Wang, Q., Li, Y.L., Wang, Z. Structural and Optical Properties of ZnO Thin Films with Heavy Cu-Doping Prepared by Magnetron Co-Sputtering Materials Letters 143 2015: pp. 319-321. https://doi.org/10.1016/j.matlet.2014.12.133

17. Allabergenov, B., Tursunkulov, O., Abidov, A.I., Byeongdae, C., Wook, J.S., Kim, S. Microstructural Analysis and Optical Characteristics of $\mathrm{Cu}$-Doped $\mathrm{ZnO}$ Thin Films Prepared by DC Magnetron Sputtering Journal of Crystal Growth 401 2014: pp. 573-576. https://doi.org/10.1016/j.jcrysgro.2014.01.040

18. Joshi, K., Rawat, M., Gautam, S.K., Singh, R.G., Ramola, R.C., Singh, F. Band gap Widening and Narrowing in $\mathrm{Cu}$-Doped $\mathrm{ZnO}$ Thin Films Journal of Alloys and Compounds 680 2016: pp. 252-258. https://doi.org/10.1016/j.jallcom.2016.04.093

19. Purohit, A., Chander, S., Sharma, A., Nehra, S.P., Dhaka, M.S. Impact of Low Temperature Annealing on Structural, Optical, Electrical and Morphological Properties of $\mathrm{ZnO}$ Thin Films Grown by RF Sputtering for Photovoltaic Applications Optical Materials 49 2015: pp. 51-58. https://doi.org/10.1016/j.optmat.2015.08.021

20. Bhatti, K.P., Chaudhary, S., Pandya, D.K., Kashyap, S.C. On the Room-Temperature Ferromagnetism in $(\mathrm{ZnO})_{0.98}\left(\mathrm{MnO}_{2}\right)_{0.02} \quad$ Solid State Communications $136(7)$ 2005: pp. $384-388$. https://doi.org/10.1016/j.ssc.2005.09.002

21. Karamat, S., Mahmood, S., Lin, J.J., Pan, Z.Y., Lee, P., Tan, T.L., Springhama, S.V., Ramanujan, R.V. Structural, Optical and Magnetic Properties of $(\mathrm{ZnO})_{1-\mathrm{x}}\left(\mathrm{MnO}_{2}\right)_{\mathrm{x}}$ Thin Films Deposited at Room Temperature Applied Surface Science $254(22)$ 2008: pp. 7285-7289. https://doi.org/10.1016/j.apsusc.2008.05.318

22. Sun, J.L., Xu, J., Zhu, J.L. Oxidized Macroscopic-long $\mathrm{Cu}$ Nanowire Bundle Photoconductor Applied Physics Letters 90 (20) 2007: pp. 201119. https://doi.org/10.1063/1.2741131

23. Sakellis, I. Determining the Activation Volumes in $\mathrm{ZnO}$ Journal of Applied Physics 112 (1) 2012: pp. 034302. https://doi.org/10.1063/1.4729486

24. Pankove, J.I. Pankove, J. Optical Process in Semiconductors, Dover, New York, 1971. 
25. Hassanien, A.S., Aly, K.A., Akl, A.A. Study of Optical Properties of Thermally Evaporated ZnSe Thin Films Annealed at Different Pulsed Laser Powers Journal of Alloys and Compounds 685 2016: pp. 733-742.

https://doi.org/10.1016/j.jallcom.2016.06.180

26. Hassanien, A.S. Studies on Dielectric Properties, Optoelectrical Parameters and Electronic Polarizability of Thermally Evaporated Amorphous $\mathrm{Cd}_{50} \mathrm{~S}_{50-\mathrm{x}} \mathrm{Se}_{\mathrm{x}}$ Thin Films Journal of Alloys and Compounds 671 2016: pp. 566-578.

https://doi.org/10.1016/j.jallcom.2016.02.126
27. Ferhat, M., Zaoui, A., Ahuja, R. Magnetism and Band Gap Narrowing in $\mathrm{Cu}$-Doped $\mathrm{ZnO}$ Applied Physics Letters 94 (14) 2009: pp. 142502-142502-3. https://doi.org/10.1063/1.3112603

28. Feng, X.B., Ang, Y.L., He, J., Beh, C.W.J., Xu, H.R., Chin, W.S., Ji, W. Three-Photon Absorption in Semiconductor Quantum Dots: Experiment Optics Express 16 (10) 2008: pp. 6999.

https://doi.org/10.1364/OE.16.006999 